\title{
Pengaruh Pemberian Auksin (NAA) Terhadap Pertumbuhan Tunas Tajuk Dan Tunas Cabang Akar Bibit Karet (Hevea brasillensis Muell. Arg) Okulasi Mata Tidur
}

\author{
Rikardo A.S.Tamba ${ }^{*}$, Dede Martino dan Sarman \\ Jurusan Agroekoteknologi Fakultas Pertanian, Universitas Jambi \\ Jl. Raya Jambi - Ma. Bulian KM. 15 Kampus Pinang Masak, Mendalo Darat, 36361

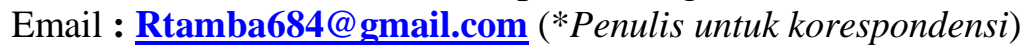

\begin{abstract}
ABSTRAK
Penelitian ini bertujuan untuk mengetahui pengaruh pemberian auksin (NAA) terhadap pertumbuhan tunas tajuk dan tunas cabang akar bibit karet okulasi mata tidur (Hevea brasillensis Muell. Arg). Penelitian ini dilaksanakan di Teaching and Research Farm Fakultas Pertanian Universitas Jambi, Mendalo Indah, Kecamatan Jambi Luar Kota, Kabupaten Muaro Jambi. Penelitian ini menggunakan Rancangan Acak Kelompok (RAK) yang terdiri dari 5 perlakuan yaitu A0 : Tanpa Perlakuan, A1 : Pemberian Auksin (NAA) 25 ppm, A2 : Pemberian Auksin (NAA) 50 ppm, A3 : Pemberian Auksin (NAA) 75 ppm dan A4 : Pemberian Auksin (NAA) 100 ppm. Variabel yang diamati meliputi persentase mentis, hari muncul tunas, panjang tunas okulasi, diameter tunas okulasi, jumlah daun, jumlah akar, panjang total akar, bobot kering tajuk dan bobot kering akar. Hasil penelitian ini menunjukkan bahwa pemberian auksin (NAA) terhadap pertumbuhan tunas tajuk dan tunas cabang akar stum okulasi mata tidur karet menunjukkan reaksi. Pemberian Auksin (NAA) 25 ppm menunjukkan konsentrasi terbaik dibandingkan perlakuan lainya dan tanpa perlakuan pada variabel pengamatan persentase mentis, diameter tunas, jumlah daun, panjang akar dan berat kering akar.
\end{abstract}

Kata kunci : Stum mata tidur Karet, Tunas tajuk, Tunas cabang akar, Auksin (NAA)

\section{PENDAHULUAN}

Tanaman Karet merupakan komoditas perkebunan yang memberikan sumber devisa yang besar dengan areal perkebunan yang luas dan sumber lapangan kerja yang besar. Nilai ekspor karet US\$ 11.8 milyar dan memberikan sumber lapangan kerja utama lebih dari 16 juta orang pada tahun 2011 (Balai Penelitian Sembawa, 2012). Luas areal perkebunan karet 3.45 juta ha dengan produksi 2.73 juta ton pada tahun 2010 (Dirjenbun, 2011). Luas areal dan produksi tanaman perkebunan rakyat provinsi Jambi dapat dilihat dalam pada Tabel 1. 
Tabel 1. Luas dan produktivitas Tanaman perkebunan rakyat Provinsi Jambi Tahun 20132015.

\begin{tabular}{|c|c|c|c|c|c|}
\hline \multirow{2}{*}{ Tahun } & \multicolumn{3}{|c|}{ Luas areal/ area $(\mathrm{Ha})$} & \multirow{2}{*}{$\begin{array}{l}\text { Produksi } \\
\text { (Ton) }\end{array}$} & \multirow{2}{*}{$\begin{array}{c}\text { Produktivitas } \\
\text { (Kg/Ha) }\end{array}$} \\
\hline & TBM & TM & TTM/TR & & \\
\hline 2013 & 197.881 & 350.457 & 113.875 & 323.271 & 922 \\
\hline 2014 & 194.284 & 345.386 & 125.925 & 318.348 & 922 \\
\hline 2015 & 196.906 & 356.282 & 111.516 & 328.563 & 922 \\
\hline & TR & $\begin{array}{l}\text { an Belum N } \\
\text { in Menghas } \\
\text { in Tua Men }\end{array}$ & asilkan & Rusak & \\
\hline
\end{tabular}

Sumber : Dinas Perkebunan Provinsi Jambi 2013-2015

Pada Tabel 1. Memperlihatkan bahwa tiga tahun terakhir perkembangan luas areal produksi perkebunan karet rakyat mengalami fluktuasi naik turun tetapi pada produktivitas tetap sama yaitu $922 \mathrm{Kg} / \mathrm{ha}$. Tahun 2014 produksi karet terendah yaitu 318.348 ton dan produksi karet tertinggi yaitu pada tahun 2015 dengan produksi 328.563 ton. Luas tanaman karet tua terendah yaitu pada tahun 2015 yaitu 111.516 ha sedangkan luas tanaman karet tua tertinggi yaitu pada tahun 2014 yaitu 125.925 ha.

Produktivitas karet rakyat di Provinsi Jambi masih rendah bila dibandingkan dengan produktivitas Perkebunan Besar Swasta dan Perkebunan Besar Negara (Bobihoe, 2012). Tahun 2013 produktivitas perkebunan karet rakyat sebesar $854 \mathrm{~kg} / \mathrm{ha} / \mathrm{tahun}$ dengan total luas lahan 381.703 ha, sedangkan pada perkebunan karet swasta produktivitas sebesar $1.221 \mathrm{~kg} / \mathrm{ha} /$ tahun dengan total luas lahan 3.073 ha. Rendahnya produktivitas perkebunan karet rakyat terjadi karena beberapa penyebab diantaranya adalah bahan tanam yang digunakan bukan berasal dari klon unggul, teknik pengelolaan yang dilakukan secara sederhana, perawatan yang memadai dan juga salah satu penyebabnya adalah faktor teknik budidaya serta kemampuan sumberdaya petani masih rendah (Sadikin dan Irawan, 2013). Jadi agar terjadi peningkatan produksi karet khususnya pada perkebunan rakyat, bahan tanam karet yang dianjurkan adalah bahan tanaman klon yang diperbanyak secara okulasi (Setiawan dan Andoko, 2005), sehingga produksi pada tahun sadap pertama lebih tinggi serta memiliki sifat sekunder yang diinginkan seperti relatif tahan terhadap penyakit tertentu, batang tegap, responsif terhadap stimulan dan pupuk, serta volume kayu perpohon tinggi (Sagala, 2009).

Stum mata tidur karet memiliki kelemahan persentase kematian bibit pada saat pembibitan lebih besar maka untuk meningkatkan tanaman tumbuh dengan baik yaitu salah satunya menggunakan Zat Pengatur Tumbuh (ZPT). ZPT merupakan senyawa organik 
bukan hara, yang dalam jumlah sedikit dapat mendukung, menghambat dan dapat mengubah proses fisiologi tumbuhan. Fungsi ZPT tersebut adalah untuk merangsang pertumbuhan morfogenesis dalam kultur sel, jaringan dan organ (Gunawan, 1995). Salah satu jenis auksin sintetik yang sering digunakan adalah NAA (Naphthalene Acetic Acid) karena NAA mempunyai sifat lebih stabil dan tidak mudah terdegradasi dari pada IAA dan yang lainya (Fitrianti, 2008). Penggunaan zat pengatur tumbuh ini menyebabkan pembentukan akar lebih cepat dan panjang, membentuk suatu sistem perakaran yang kuat, kompak dan menyerabut (Rahardiyanti, 2005).

Pemberian Auksin (dengan merek dagang growtone) 50mg/0,5ml air pertanaman dapat meningkatkan waktu muncul mata tunas bibit karet yaitu 25,30 hari dan terendah pada tanpa perlakuan yaitu 30,80 hari. Pemberian Auksin 50mg/0,5ml air pertanaman dapat meningkatkan tinggi tunas bibit karet yaitu 41,60 $\mathrm{cm}$ dan terendah pada tanpa perlakuan yaitu $18,70 \mathrm{~cm}$. Pemberian Auksin $50 \mathrm{mg} / 0,5 \mathrm{ml}$ air pertanaman dapat meningkatkan jumlah daun yaitu 20,20 dan terendah pada tanpa perlakuan yaitu 10,20. Pemberian Auksin 50mg/0,5ml air pertanaman dapat meningkatkan dapat meningkatkan diameter tunas yaitu $5,30 \mathrm{~mm}$ dan terendah pada tanpa perlakuan yaitu $3,10 \mathrm{~mm}$ (Alfiansyah et al., 2015). Selain itu pada penelitian Yuliantina et al., (2013) menyatakan bahwa Auksin (dengan merek dagang hormax) $8 \mathrm{ml} / \mathrm{L}$ dapat meningkatkan kecepatan tumbuh tunas yaitu 20,40 hari dan terendah pada perlakuan $6 \mathrm{ml} / \mathrm{L}$ yaitu 22,71hari. Pemberian $8 \mathrm{ml} / \mathrm{L}$ dapat meningkatkan panjang tunas yaitu $30,79 \mathrm{~cm}$ dan terendah pada perlakuan $6 \mathrm{ml} / \mathrm{L}$ yaitu $21,34 \mathrm{~cm}$. Pemberian $2 \mathrm{ml} / \mathrm{L}$ dapat meningkatkan jumlah daun yaitu 8 dan terendah pada perlakuan $6 \mathrm{ml} / \mathrm{L}$ yaitu 7,13. Pemberian $8 \mathrm{ml} / \mathrm{L}$ dapat meningkatkan persentase bibit tumbuh yaitu $80 \%$ dan terendah pada perlakuan $6 \mathrm{ml} / \mathrm{L}$ yaitu $64 \%$. Pemberian $8 \mathrm{ml} / \mathrm{L}$ dapat meningkatkan bobot basah tanaman yaitu 16,24 $\mathrm{g}$ dan terendah pada perlakuan $6 \mathrm{ml} / \mathrm{L}$ yaitu $14,07 \mathrm{~g}$. Pemberian $8 \mathrm{ml} / \mathrm{L}$ dapat meningkatkan bobot kering tanaman yaitu 7,10 g dan terendah pada perlakuan $6 \mathrm{ml} / \mathrm{L}$ yaitu 4,79 g. Pemberian $8 \mathrm{ml} / \mathrm{L}$ dapat meningkatkan bobot kering akar yaitu 0,88 g dan terendah pada perlakuan $6 \mathrm{ml} / \mathrm{L}$ yaitu 0,56 g. Selanjutnya hasil penelitian Monica et al., (2017) Pemberian Auksin (NAA) 100 ppm dapat meningkatkan panjang bibit bud set tanaman Tebu yaitu 125,94 cm dan terendah pada pemberian 200 ppm yaitu 110,46 cm. Pemberian 100 ppm dapat meningkatkan jumlah daun yaitu 9,62 helai dan terendah pada pemberian 300 ppm yaitu 8,78 helai. Pemberian 100 ppm dapat meningkatkan diameter batang yaitu 15,2 $\mathrm{mm}$ dan terendah pada pemberian $300 \mathrm{ppm}$ yaitu 13,56 mm. Panjang akar tertinggi diperoleh pada tanpa pemberian NAA yaitu $33,26 \mathrm{~cm}$ dan terendah pada pemberian 300 
ppm yaitu31,95 cm. Bobot basah akar tertinggi diperoleh pada tanpa pemberian NAA yaitu $14,11 \mathrm{~g}$ dan terendah pada pemberian $300 \mathrm{ppm}$ yaitu 12,45 g. Bobot kering akar tertinggi pada tanpa perlakuan yaitu $3,44 \mathrm{~g}$ dan terendah pada pemberian $300 \mathrm{ppm}$ yaitu $2,75 \mathrm{~g}$. Pemberian 100 ppm dapat meningkatkan bobot basah tajuk yaitu 61,85 g dan terendah pada pemberian 200 ppm yaitu 42,4 g. Pemberian 100 ppm dapat meningkatkan bobot kering tajuk yaitu 19,58 g dan terendah pada pemberian 300 ppm yaitu 15,7 g.

\section{BAHAN DAN METODE}

Penelitian ini dilaksanakan di Teaching and Research Farm Fakultas Pertanian Universitas Jambi, Desa Mendalo Indah, Kecamatan Jambi Luar Kota, Kabupaten Muaro Jambi. Penelitian dilaksanakan pada bulan Desember (2017) sampai Maret 2018. Bahan yang digunakan adalah tanah, ajir, bibit karet stum mata tidur klon PB 260 (Lampiran 3), ZPT Auksin (NAA), pupuk NPK 16:16:16 dan polybag ukuran $15 \times 30 \mathrm{~cm}$. Alat yang digunakan adalah cangkul, parang, ember, gembor, meteran, jangka sorong, tali rafia, oven, timbangan analitik, gunting, sekop, kayu, kamera, dan alat tulis.

Penelitian ini menggunakan Rancang Acak Kelompok (RAK) dengan berbagai perlakuan konsentrasi ZPT Auksin (NAA) dengan 5 perlakuan dan 3 Kelompok, yaitu:

$\mathrm{A}_{0}$ : Tanpa pemberian Auksin (NAA).

$\mathrm{A}_{1}$ : pemberian Auksin (NAA) $25 \mathrm{ppm}$.

$\mathrm{A}_{2}$ : pemberian Auksin (NAA) $50 \mathrm{ppm}$.

$\mathrm{A}_{3}$ : pemberian Auksin (NAA) $75 \mathrm{ppm}$.

$\mathrm{A}_{4}:$ pemberian Auksin (NAA) $100 \mathrm{ppm}$.

Variabel pengamatan adalah persentase mentis, hari muncul tunas, panjang tunas, diameter tunas, jumlah daun, jumlah akar, panjang total akar, bobot kering tajuk dan bobot kering akar. Data hasil pengamatan dianalisis secara statistik dengan menggunakan analisis ragam. Untuk melihat adanya perbandingan kemudian dilanjutkan dengan uji Duncan Multiple Range Test (DMRT) pada taraf $\alpha=5 \%$..

\section{HASIL DAN PEMBAHASAN}

Hasil penelitian terhadap variabel persentase mentis, hari muncul tunas, panjang tunas, diameter dan jumlah daun pada bibit karet disajikan pada Tabel 2. 
Tabel 2. Rata-rata persentase mentis, hari muncul tunas, panjang tunas, diameter dan jumlah daun

\begin{tabular}{|c|c|c|c|c|c|}
\hline Perlakuan & $\begin{array}{l}\text { Persentase } \\
\text { Mentis }\end{array}$ & $\begin{array}{c}\text { Hari } \\
\text { Muncul } \\
\text { Tunas }\end{array}$ & $\begin{array}{c}\text { Panjang } \\
\text { Tunas }(\mathrm{cm})\end{array}$ & $\begin{array}{l}\text { Diameter } \\
(\mathrm{mm})\end{array}$ & $\begin{array}{l}\text { Jumlah } \\
\text { Daun }\end{array}$ \\
\hline Tanpa Perlakuan & $88,89 \mathrm{~b}$ & $22,25 \mathrm{a}$ & 26,5 a & $5,99 \mathrm{c}$ & $10,66 \mathrm{~b}$ \\
\hline $25 \mathrm{ppm}$ & 100 & $21,08 \mathrm{a}$ & $28,65 \mathrm{a}$ & $6,70 \mathrm{ab}$ & $11,25 \mathrm{ab}$ \\
\hline $50 \mathrm{ppm}$ & 100 & $20,75 \mathrm{a}$ & $32,63 \mathrm{a}$ & $6,37 \mathrm{bc}$ & $11,16 \mathrm{ab}$ \\
\hline 75 ppm & 100 & $19,33 \mathrm{a}$ & $33,79 \mathrm{a}$ & $7,08 \mathrm{a}$ & $11,91 \mathrm{a}$ \\
\hline 100 ppm & 100 & $22,16 \mathrm{a}$ & 27,9 a & $6,25 \mathrm{bc}$ & $10,66 \mathrm{~b}$ \\
\hline
\end{tabular}

Keterangan: Angka-angka yang diikuti oleh huruf yang berbeda menunjukkan berbeda nyata menurut Uji Duncan dengan taraf $\alpha=5 \%$

Berdasarkan hasil penelitian pada Tabel 2 menunjukkan bahwa pemberian auksin (NAA) terhadap pertumbuhan tunas tajuk dan tunas cabang akar stum okulasi mata tidur karet memberikan perbedaan yang nyata terhadap persentase mentis, diameter dan jumlah daun, namun tidak berbeda nyata terhadap hari muncul tunas dan panjang tunas.

Perlakuan pemberian konsentrasi $25 \mathrm{ppm}$ menunjukkan persentase mentis tercepat dari perlakuan lainya dan tanpa perlakuan yaitu $100 \%$ pada tanpa perlakuan menunjukan persentase mentis terlama yaitu 88,89\%. Hal ini diduga karena pemberian Auksin (NAA) pada stum okulasi karet dapat membatu persentase mentis bibit karet. Hal ini didukung oleh penelitian Mirna et al., (2013) bahwa bio-urine sapi yang mengandung auksin IAA sebanyak 704,26 mg/l dapat meningkatkan persentase tumbuh mata tunas tanaman karet pada konsentrasi $5 \%$, 7,5 dan $10 \%$ yaitu mencapai $100 \%$. Sebagaimana dikemukakan Gardner et al., (2008), auksin IAA dikenal sebagai auksin pada tanaman yang mana pada konsentrasi tertentu dapat merangsang tanaman.

Perlakuan pemberian konsentrasi 75 ppm menunjukkan rata-rata hari muncul tunas tercepat yaitu 19,33 hari pada tanpa perlakuan menunjukkan hari muncul tunas terlama yaitu 22,25 hari. Hal ini berkaitan dengan panjang total akar, pemberian auksin NAA tidak berbeda nyata satu sama lainnya. Hal ini diduga pada tanah yang digunakan dalam penelitian ini mengandung $\mathrm{pH}$ yang rendah, bahan organik yang rendah serta didominasi oleh liat sehingga mengganggu proses perkembangan akar pada stum okulasi karet. Menurut Marchino (2011) waktu tumbuh mata tunas bibit karet stum mata tidur ada kaitanya dengan proses pembentukan dan perkembangan akar. Apabila akar telah terbentuk dan berkembang dengan baik maka tunas juga akan ikut terbentuk. Pada bibit karet stum mata tidur, pembentukan akar pertama kali lebih didorong oleh cadangan 
makanan yang ada pada batang bawah, sehingga pertumbuhan tunas-tunas baru juga terpacu. Menurut Darnell et al., (1986) dalam Alfiansyah (2015) menyatakan salah satu peran Auksin adalah menstimulasi atau mempercepat terjadinya perpanjangan sel. Pemberian auksin eksogen akan meningkatkan aktifitas auksin endogen yang sudah ada pada tanaman, sehingga mendorong pembelahan sel dan menyebabkan tunas muncul lebih awal. Auksin merupakan salah satu hormon tanaman yang dapat meregulasi banyak proses fisiologi seperti pertumbuhan, pembelahan dan diferensiasi sel serta sintesa protein.

Perlakuan pemberian konsentrasi 75 ppm menunjukkan rata-rata panjang tunas bibit karet tertinggi yaitu 33,79 $\mathrm{cm}$ pada tanpa perlakuan menunjukkan panjang tunas terendah yaitu $26,5 \mathrm{~cm}$. Hal ini karena tanah yang digunakan pada penelitian didominasi oleh liat sehingga akar tanaman pada stum okulasi karet sulit untuk berkembang. Selain sulit berkembang, ketersediaan unsur hara pada tanah penelitian ini tergolong rendah yang menyebabkan proses pertumbuhan akar pada tanaman yang terganggu. Auksin (NAA) yang diberikan pada tanaman tidak sebagai penambah unsur hara melainkan sebagai perangsang pertumbuhan morfogenesis dalam sel, jaringan dan organ.

Perlakuan pemberian konsentrasi 75 ppm menunjukkan rata-rata diameter bibit karet tertinggi yaitu 7,08 mm pada tanpa perlakuan menunjukkan diameter terendah yaitu 5,99 $\mathrm{mm}$. Proses pertumbuhan diameter tunas berhubungan dengan pertumbuhan panjang tunas. Pertumbuhan diameter tunas disebabkan karena setelah pembelahan sel, akan terjadi pembesaran sel yang berarti bahwa masing-masing sel menjadi lebih besar. Seperti juga dengan pembelahan sel, pembesaran sel juga terjadi di daerah meristem dan mengakibatkan pertambahan luas dinding sel sehingga pertumbuhan diameter batang akan semakin cepat sehingga pertumbuhan diameter akan semakin besar (Darmawan dan Justika. 2010).

Perlakuan pemberian konsentrasi 75 ppm menunjukkan rata-rata jumlah daun bibit karet tertinggi yaitu 11,91 helai pada tanpa perlakuan menunjukkan jumlah daun terendah yaitu 10,66 helai. Suwarno (2010) menyatakan pemberian auksin pada awal penanaman dapat merangsang pertumbuhan sel ujung mata tunas, pertumbuhan akar lateral dan akar serabut serta merangsang pembentukan mata tunas dan daun dengan cepat, sehingga tahap selanjutnya proses fotosintesis terjadi selain itu pertumbuhan tanaman kepada ketersedian air dan unsur hara pada media.

Hasil penelitian terhadap variabel jumlah akar, panjang total akar, bobot kering tajuk dan bobot kering akar bibit karet disajikan pada Tabel 3 . 
Tabel 3. Rata-rata jumlah akar, panjang total akar, bobot kering tajuk dan bobot kering akar

\begin{tabular}{ccccc}
\hline Perlakuan & Jumlah Akar & $\begin{array}{c}\text { Panjang Total } \\
\text { Akar }(\mathrm{cm})\end{array}$ & $\begin{array}{c}\text { Bobot Kering } \\
\text { Tajuk }(\mathrm{g})\end{array}$ & $\begin{array}{c}\text { Bobot Kering } \\
\text { Akar }(\mathrm{g})\end{array}$ \\
\hline Tanpa perlakuan & $27,83 \mathrm{a}$ & $229,19 \mathrm{ab}$ & $229,19 \mathrm{ab}$ & $23,28 \mathrm{~b}$ \\
$25 \mathrm{ppm}$ & $29 \mathrm{a}$ & $218,05 \mathrm{ab}$ & $218,05 \mathrm{ab}$ & $23,38 \mathrm{~b}$ \\
$50 \mathrm{ppm}$ & $30,25 \mathrm{a}$ & $233,17 \mathrm{ab}$ & $233,17 \mathrm{ab}$ & $25,8 \mathrm{ab}$ \\
$75 \mathrm{ppm}$ & $35,08 \mathrm{a}$ & $276,42 \mathrm{a}$ & $276,42 \mathrm{a}$ & $31,89 \mathrm{a}$ \\
$100 \mathrm{ppm}$ & $23,75 \mathrm{a}$ & $167,98 \mathrm{~b}$ & $167,98 \mathrm{~b}$ & $26,7 \mathrm{ab}$ \\
\hline
\end{tabular}

Keterangan: Angka-angka yang diikuti oleh huruf yang berbeda menunjukkan berbeda nyata menurut Uji Duncan dengan taraf $\alpha=5 \%$

Berdasarkan hasil penelitian pada Tabel 3 menunjukkan bahwa pemberian auksin (NAA) terhadap pertumbuhan tunas tajuk dan tunas cabang akar stum okulasi mata tidur karet memberikan perbedaan yang nyata terhadap panjang total akar, bobot kering tajuk dan bobot kering akar namun tidak berbeda nyata dengan jumlah akar.

Perlakuan pemberian konsentrasi 75 ppm menunjukkan rata-rata jumlah akar bibit karet terbanyak yaitu 35,08 pada perlakuan 100 ppm menunjukkan jumlah akar bibit karet terendah yaitu 23,75. Hal ini didukung oleh Salisbury dan Ros (1992) yang menyatakan bahwa dengan pemberian auksin pada konsentrasi yang optimal dapat memacu perkembangan akar karena adanya Auksin yang mengalir dari bagian meristem apikal menuju bagian basal tanaman, karbohidrat dalam tanman akan mengumpul untuk memacu pembentukan akar

Perlakuan pemberian konsentrasi 75 ppm menunjukkan rata-rata panjang total akar bibit karet terbanyak yaitu 276,42 cm pada perlakuan 100 ppm menunjukkan panjang total akar bibit karet terendah yaitu 167,98 cm. Hal ini didukung oleh Salisbury dan Ros (1992) yang menyatakan bahwa dengan pemberian auksin pada konsentrasi yang optimal dapat memacu pemanjangan akar.

Perlakuan pemberian konsentrasi 75 ppm menunjukkan rata-rata bobot kering tajuk bibit karet tertinggi yaitu $6,73 \mathrm{~g}$ pada tanpa perlakuan menunjukkan bobot kering tajuk bibit karet terendah yaitu 4,83 g. Berat kering tajuk diperoleh dengan cara mengopen berat basah tajuk tanaman dan kemudian dipanaskan dengan suhu $80{ }^{\circ} \mathrm{C}$ hingga mendapatkan berat kering konstan. Hal ini diduga pemberian auksin dengan konsentrasi 75 ppm meningkatkan nilai berat kering tajuk. Menurut Iswandi (1998) menyatakan bahwa dengan penambahan Auksin (NAA) memberikan tanggapan positif terhadap proses perkembanan jaringan, secara langsung akan mempengaruhi kecepatan pertumbuhan dan perkembangan 
secara keseluruhan. Selain itu jumlah unsur hara yang diserap oleh tanaman umumnya selalu berbanding lurus dangan laju pertumbuhan dan berat kering tanaman.

Perlakuan pemberian konsentrasi 75 ppm menunjukkan rata-rata bobot kering akar bibit karet tertinggi yaitu 31,89 g pada tanpa perlakuan menunjukkan bobot kering tajuk bibit karet terendah yaitu 23,28 g.Hal ini sejalan dengan panjang akar dimana pemberian auksin 75 ppm merupakan panjang akar tertinggi dibandingkan dengan konsentrasi lainnya. Berat kering akar diperoleh dengan cara mengoven berat basah akar tanaman dan kemudian dipanaskan dengan suhu $80{ }^{\circ} \mathrm{C}$ hingga mendapatkan berat kering konstan. Wattimena (1992) menyatakan bahwa Auksin (NAA) mempunyai sifat translokasi yang lambat, persistensinya tinggi dan aktivitas yang rendah sehingga mendorong pembentukan akar. Dengan peningkatan pembelahan sel tersebut menyebabkan ketersedian air dalam sel juga meningkat. Menurut Salisburry dan Ross (1992) bahwa ketersedian air yang lebih banyak akan meningkatkan pertumbuhan sehingga berat kering juga meningkat.

\section{KESIMPULAN}

1. Bahwa pemberian Auksin (NAA) terhadap pertumbuhan tunas tajuk dan tunas cabang akar stum okulasi mata tidur karet (Hevea brasiliensis Muell. Arg.) memberikan pertumbuhan yang lebih baik terhadap persentase mentis, diameter, jumlah daun, panjang akar dan bobot kering akar dibandingkan dengan tanpa perlakuan tetapi tidak berbeda nyata terhadap hari muncul tunas, panjang tunas okulasi, jumlah akar dan berat kering tajuk.

2. Pemberian perlakuan Auksin (NAA) 25 ppm merupakan konsentrasi terbaik di bandingkan perlakuan lainya dan tanpa perlakuan pada variabel pengamatan diameter tunas, jumlah daun, panjang akat dan berat kering akar.

\section{DAFTAR PUSTAKA}

Alfiansyah, Sukemi IS dan Khoiri MA.2015. Pemberian Zat Pengatur Tumbuh Auksin dengan Berbagai Konsentrasi pada Bibit Karet (Hevea brasilliensis Muell Arg) Stum Mata Tidur Klon PB 260. Jurnal Agroekoteknologi Fakultas Pertanian Universitas Riau. Vol 2 No 1 Februari 2015.

Balai Penelitian Perkebunan Sembawa. 2012. Pengelolaan Perkebunan. Pusat Penelitian Perkebunan Sembawa. Palembang. 
Bobihoe, J. 2012. Peningkatan Kesejahteraan Petani Melalui Perbaikan Teknologi Budidaya Karet Rakyat di Provinsi Jambi.Balai Pengkajian Teknologi Pertanian (BPTP) Jambi.Jambi.

Darmawan, J. Justika. S,B. 2010. Dasar - Dasar Fisiologi Tanaman. SITC. Jakarta.

Dinas Perkebuna Provinsi Jambi. 2013-2015. Statisik Perkebunan Provinsi Jambi. Dinas Perkebunan; Jambi.

Direktorat Jenderal Perkebunan. 2011. Statistik Perkebunan Indonesia 2011 Karet. Direktorat Jenderal Perkebunan; Jakarta.

Fitriani, H. 2008. Kajian Konsentrasi BAP dan NAA terhadap Multiplikasi Tanaman Artemisia annuaL. secara In Vitro.Skripsi Fakultas Pertanian UNS. Surakarta.

Gardner, F.P., Brent R.P., Rogel L.M. 2008. Fisiologi Tanaman Budidaya. UI Press. Depok.

Gunawan LW. 1995. Teknik Kultur In vitro dalam Hortikultura. Jakarta (ID): Penebar Swadaya.

Iswandi.1998. Pengaruh Kombinasi Bahan Stek dan Zat Pengatur Tumbuh Indole-3 Butyric Acid (IBA) Terhadap Keberhasilan dan Pertumbuhan Stek Kakao (Theobroma cacao L.).Skrpsi. Fakultas Pertanian. Universitas Andalas. Padang.

Marchimo, F. 2011. Pertumbuhan Stum Mata Tidur beberapa Klon Entres Tanaman Karet (Hevea brasiliensis Muell.)Pada batang bbawah PB 260 di Lapangan.Skripsi. Fakultas Pertanian. Universitas Andalas.

Mirna N, E.F. H. Salim dan Z.F Gani. 2013. Pengaruh Biourine Sapi Terhadap Pertumbuhan Bibit Karet (Hevea brasiliensis Muell. Arg) Asal Stum Mata Tidur. Fakultas Pertanian Universitas Jambi ; Jambi. Vol 2 No. 1 Januari - Maret 2013 (ISSN : 2302-6472).

Monica, Y., Meiriani dan Barus A. 2017. Pertumbuhan Berbagai Umur Bahan Tanam Bud Set Tebu (Saccharum officinarum L.)dengan Konsentrasi NAA yang Berbeda. Universitas Sumatera Utara; Medan. Jurnal Agroekoteknologi FP USU Vol. 5. No. 2, April 2017(39): 297-306.

Rahardiyanti, R. 2005. Kajian Pertumbuhan Stek Batang Sangitan (Sambucus javanica Reinw.) di Persemaian dan Lapangan.Skripsi.IPB.Bogor.

Sadikin, I. dan R. Irawan. 2013. Dampak Pembangunan Perkebunan KaretRakyatTerhadap Kehidupan Petani di Riau. Pusat Penelitian dan Pengembangan Sosial Ekonomi Pertanian. Bogor.

Sagala, A.D., 2009. Teknis Budidaya Tanaman karet. Balai Penelitian Sungei Putih. Pusat Penelitian Karet. Galang. 
Salisbury, F.B. dan C.W. Ross. 1992. Plant Physiology 4th edition. Terjemahan.Penerbit ITB. Bandung.

Setiawan, D. H. dan A. Andoko., 2005. Petunjuk Lengkap Budidaya Karet.AgroMedia Pustaka, Jakarta.

Suwarno. 2010. Tahap-Tahap Pertumbuhan Tanaman. http://wwwTahaptahappertumbuhan-tanaman.com.Diakses pada tanggal 21 April 2018.

Wattimena GA, 1988. Zat Pengatur Tumbuh Tanaman. Bogor (ID): Pusat antar Universitas (PAU) IPB.

Yuliantina, Eddy U dan Novran P. 2013. Pengaruh Pemberian Zat Pengatur Tumbuh Terhadap Pertumbuhan Stum Mata Tidur Karet (Hevea brasilliensis Muell Arg.) Klon BPM 24. Jurnal Agroekoteknologi Fakultas Pertanian Universitas Tridinanti Palembang. 5 (1) : 25-30, Juli 2013. 